\title{
Bacterial glutaminase in treatment of acute leukaemia
}

\author{
A S D SPIERS, H E WADE
}

British Medical fournal, 1976, 1, 1317-1319

was measured in some patients and the bone marrow was examined if leukaemic cells were absent from the blood.

Glutaminase-The enzyme was purified to a homogenous preparaSummary

A glutaminase-asparaginase enzyme from Achromobacter sp has antitumour activity in vitro and in animals. Glutaminase was administered in doses of 3500-20 000 $\mathrm{IU} / \mathrm{m}^{2}$ body surface area/day to six patients with acute lymphoblastic leukaemia (ALL) and three patients with acute myeloid leukaemia (AML). The enzyme had a blood half life of 80 minutes but depletion of blood glutamine persisted for 12 hours after single doses. Seven patients, including four (two with AML and two with ALL) resistant to asparaginase, received repeated doses of glutaminase. Antileukaemic effects were observed in all seven; one elderly patient developed metabolic acidosis. Study of this new antileukaemic agent in patients with acute leukaemia at an earlier stage of their disease is now justified.

\section{Introduction}

Enzymes that hydrolyse L-asparagine-asparaginases-are cytotoxic to murine lymphomas in vitro $^{1}$ and in vivo. ${ }^{2}$ Asparaginases from Escherichia coli and Erwinia carotovora induce remissions in human acute leukaemias, ${ }^{3-7}$ and this prompted a search for antitumour activity among other enzymes that degrade amino-acids. A glutaminase isolated from Achromobacteraceae ${ }^{8}$ was cytocidal in vitro to cells of chronic lymphocytic leukaemia and acute leukaemias ${ }^{9}$ and inhibited the response of normal lymphocytes to phytohaemagglutinin. ${ }^{10}$ This enzyme hydrolyses both glutamine and asparagine but its effects on normal ${ }^{10}$ and leukaemic ${ }^{11}$ cells are apparently due to its glutaminase activity: its activity against asparaginase-resistant tumours ${ }^{12}$ supports this view. The cytotoxicity of glutaminase is due to depletion of glutamine per se and not to production of ammonia and glutamate. ${ }^{9}$

An achromobacter glutaminase-asparaginase was produced at Porton; its antitumour activity in vitro and in animals prompted a clinical study in acute leukaemia and we report here its first administration to man.

\section{Patients and methods}

Six patients with acute lymphoblastic leukaemia (ALL) and three with acute myeloid leukaemia (AML) received glutaminase (see table). All were in relapse after one or more remissions and their leukaemia was resistant to standard agents and to an eight-drug combination. ${ }^{13}$ Informed consent was obtained from patients or their parents. Indices measured before and during glutaminase treatment were: haemoglobin, reticulocyte and platelet counts, total and differential leucocyte counts, serum electrolytes, urea, creatinine, urate, serum aspartate aminotransferase (SGOT), cholesterol, albumin, globulin, calcium, phosphate, alkaline phosphatase, bilirubin, and blood glucose. Blood $\mathrm{pH}$

\footnotetext{
Medical Research Council Leukaemia Unit, Royal Postgraduate Medical School, London W12 0HS

A S D SPIERS, MD, FRACP, consultant physician

Microbiological Research Establishment, Porton Down, Salisbury, Wilts

H E WADE, BA, PHD, head of enzyme chemistry
} bacter glutaminase ${ }^{814}$ in expressing similar activities towards glutamine and asparagine and very high substrate affinities, but differs from it in several other biochemical and biological properties. ${ }^{15}$ It does not cross-react with antisera to acinetobacter glutaminase or to Escherichia coli or Erwinia carotovora asparaginase, ${ }^{1617}$ but an antiserum to achromobacter glutaminase partially inhibits both this enzyme and the acinetobacter glutaminase. ${ }^{17}$ The enzyme was supplied as a sterile lyophilised powder, readily soluble in physiological saline.

Blood analyses-For pharmacological studies single intravenous bolus doses of glutaminase ( 6000 to $10000 \mathrm{IU} / \mathrm{m}^{2}$ body surface area) were administered. Blood samples taken before and at intervals after this dose were frozen at the bedside with solid $\mathrm{CO}_{2}$ and stored at $-20^{\circ} \mathrm{C}$. Immediately after thawing one volume was diluted in $0.05-\mathrm{M}$ sodium borate buffer ph 8.5 for glutaminase assay, ${ }^{18}$ and a second volume $(0.5 \mathrm{ml})$ was diluted with an equal volume of protein precipitant $(2.5 \%$ sulphosalicylic acid in $0.5-\mathrm{M}$ lithium sulphite) and centrifuged. The amino-acid composition of the supernatant was analysed $^{19}$ on a Locarte analyser using nor-leucine as an internal standard. We thus determined the blood half life of the enzyme and the duration of depletion of blood glutamine and asparagine after a single intravenous dose.

Administration of glutaminase-For kinetic studies single intravenous bolus doses were used. In our preliminary study of the antileukaemic effects of the enzyme four schedules were used: (a) daily intravenous bolus injections; $(b)$ twice-daily subcutaneous injections; (c) twice-daily intravenous injections; and (d) continuous intravenous infusions of glutaminase in normal saline. When the blood half life of the drug was found to be short schedule $(d)$ was used to obtain the maximum effect from the small supplies of glutaminase then available.

\section{Results}

Blood half life-Serial blood glutaminase levels after single intravenous injections are shown in fig 1 . The half life of the enzyme was about 80 minutes; further studies are in progress.

Effect on blood amino-acids-Data were complete for five patients. One patient (case 1) received daily intravenous bolus injections beginning with $25 \mathrm{IU} / \mathrm{m}^{2}$ daily and reaching a maximum of 3500

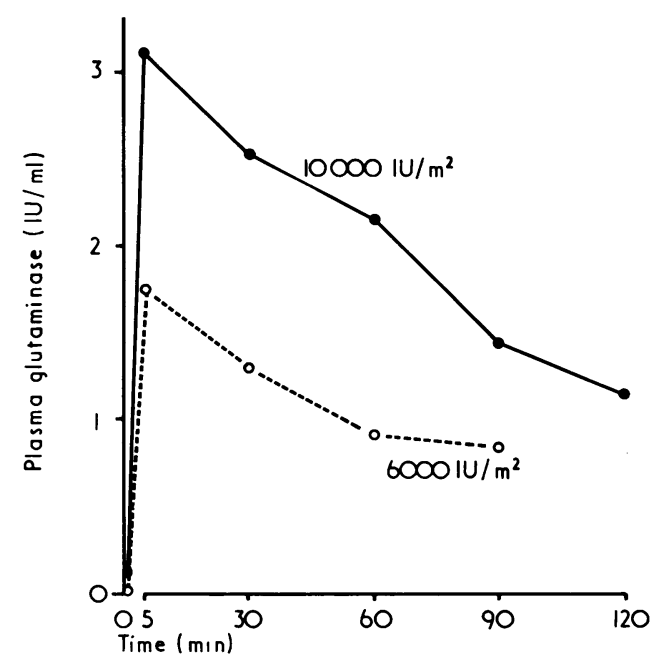

FIG 1-Serial estimations of whole blood glutaminase concentrations after single intravenous injections at time 0 in two patients. One patient (case 4 ) received $10000 \mathrm{IU} / \mathrm{m}^{2}$ and the other (case 3) $6000 \mathrm{IU} / \mathrm{m}^{2}$. Half life of the enzyme is about 80 minutes. 
Details of patients with drug-resistant acute leukaemia who received glutaminase

\begin{tabular}{|c|c|c|c|c|}
\hline $\begin{array}{l}\text { Case } \\
\text { No }\end{array}$ & Age and sex & Diagnosis & $\begin{array}{l}\text { Dose of } \\
\text { glutaminase } \\
\left.\text { (IU } \mathrm{m}^{2} / \text { day }\right)\end{array}$ & Antileukaemic effects \\
\hline 1 & $32 \mathrm{M}$ & ALL* & 3500 & $\begin{array}{l}\text { Blast cell count rebounded in } 5 \text { days after reduction to zero by cytotoxic therapy; remained zero } \\
\text { for } 2 \text { weeks when glutaminase treatment followed cytotoxic therapy and rebounded only after } \\
\text { its cessation }\end{array}$ \\
\hline 2 & $8 \mathrm{M}$ & ALL & 4000 & Blast cell count fell from 11 to $2.5 \times 10^{9} / 1$ in 6 days but rose again despite continuing \\
\hline $\begin{array}{l}3 \\
4\end{array}$ & $17 \mathrm{M}$ & $\begin{array}{l}\text { ALL† } \\
\text { ALL }\end{array}$ & $\begin{array}{l}12000 \\
20000\end{array}$ & $\begin{array}{l}\text { glutaminase } \\
\text { Blast cell count fell from } 2 \cdot 9 \text { to } 0.12 \times 10^{9} / 1 \text {; marrow blasts fell from } 75 " \text {, to } 50^{\circ} \\
\text { Resistant to asparaginase. Blast cell count fell from } 135 \text { to } 63 \times 10^{9} / 1 \text { after } 6 \text { days of } \\
\text { glutaminase; patient then died of cerebral haemorrhage; glutaminase may have exacerbated } \\
\text { thrombocytopenia }\end{array}$ \\
\hline $\begin{array}{l}5 \\
6\end{array}$ & $\begin{array}{l}40 \mathrm{~F} \\
14 \mathrm{M}\end{array}$ & $\begin{array}{l}\text { AML } \\
\text { ALL }\end{array}$ & $\begin{array}{l}10000 \\
20000\end{array}$ & $\begin{array}{l}\text { Single test dose of glutaminase } \\
\text { Resistant to asparaginase; complete regression of } 8-\mathrm{cm} \text { splenomegaly; blast cells fell from } \\
3.3 \times 10^{9} / 1 \text { to zero }\end{array}$ \\
\hline 7 & $7 \mathrm{M}$ & AML & 15000 & $\begin{array}{l}\text { Bone marrow became hypocellular but not free of blasts } \\
\text { Blast cell count fell from } 17 \times 10^{\circ} / 1 \text { to zero in } 7 \text { days; became pancytopenic; died of } \\
\text { pseudomonas septicaemia }\end{array}$ \\
\hline $\begin{array}{l}8 \\
9\end{array}$ & $\begin{array}{l}27 M \\
68 M\end{array}$ & $\begin{array}{l}\text { ALL } \\
\text { AML }\end{array}$ & $\begin{array}{l}10000 \\
20000\end{array}$ & $\begin{array}{l}\text { Single test dose of glutaminase } \\
\text { Blast cell count fell from } 8 \text { to } 0.24 \times 10^{\circ} / 1 \text { in } 4 \text { days; treatment discontinued due to acidosis }\end{array}$ \\
\hline
\end{tabular}

Conversion: SI to traditional units-Cell counts: $1 \times 10^{\gamma} / 1=1000 / \mathrm{mm}^{3}$.

† Electron microscopic appearances of acute undifferentiated leukaemia rather than ALL.

$\mathrm{IU} / \mathrm{m}^{2}$ daily for 13 days; depletion of glutamine and asparagine was not observed in any blood sample. Another patient (case 3 ) received $6000 \mathrm{IU} / \mathrm{m}^{2}$ twice daily by intravenous injection; glutamine and asparagine were undetectable one and a half hours after injections but returned to pretreatment levels by 12 hours. In cases 4 and 5 glutamine and asparagine were undetectable in the blood five minutes after single intravenous injections of $10000 \mathrm{IU} / \mathrm{m}^{2}$; depletion persisted at two hours. Another patient (case 6) received 20000 IU of glutaminase per $\mathrm{m}^{2}$ each day by continuous infusion; glutamine and asparagine were always undetectable in blood samples throughout the 28 days of administration. More detailed studies of the reappearance of glutamine and asparagine in the blood after single doses of glutaminase are in progress.

The antileukaemic effects-Despite lack of knowledge of the optimum dose and schedule and the deliberate selection of patients with leukaemias refractory to treatment the antileukaemic activity of glutaminase was convincingly shown. Its effects are summarised in the table and the responses in cases 6 and 7 are shown in figs 2 and 3 respectively. Symptomatic improvement, regression of splenomegaly, reduction in circulating blast cell count, and a decreased proportion of blast cells in the bone marrow were observed. Complete remissions did not occur in these patients, who were in a late stage of their disease and had deteriorated despite conventional antileukaemic treatment.
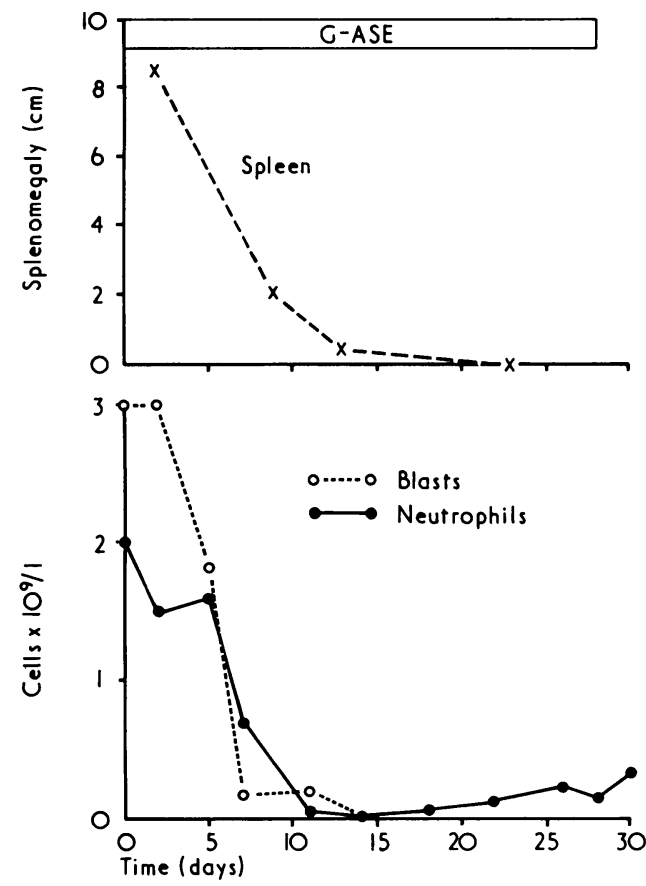

FIG 2-Case 6. Effects of continuous intravenous infusion of glutaminase $20000 \mathrm{IU} / \mathrm{m}^{2} /$ day for 28 days in patient with ALL resistant to conventional therapy including asparaginase.

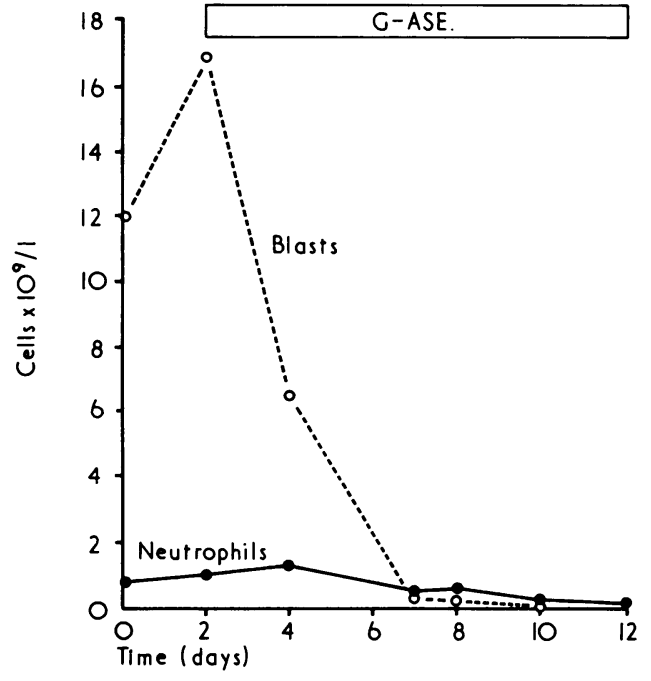

FIG 3-Case 7. Effects of a 10-day infusion of glutaminase $15000 \mathrm{IU} / \mathrm{m}^{2} /$ day in patient with AML who had not received asparaginase but was resistant to other conventional therapy.

Toxicity-No toxic effects occurred in case 2 but the other patients were nauseated and four vomited. Vomiting occurred only after initial intravenous loading doses of glutaminase. Nausea usually abated after a few days of treatment. One patient (case 7) became drowsy during glutaminase treatment. No patient developed manifestations of allergy. There was no gross disturbance in most of the biochemical indices studied. In one patient who received glutaminase for 28 days (case 6 ) there was moderate depression of serum urate, bicarbonate, cholesterol, SGOT, and calcium levels with an increase in serum phosphate concentration. The serum albumin level fell to $28 \mathrm{~g} / \mathrm{l}$ by the 10th day but rose by the 17th day. Hypouricaemia also occurred in case 4, and serum calcium and SGOT levels were depressed and serum phosphate levels increased in case 7 ; these changes were asymptomatic. Hyperglycaemia was not observed, but in case 9 metabolic acidosis (blood $\mathrm{pH} 7 \cdot 3$ ) developed on the fourth day. Neutropenia possibly attributable to glutaminase occurred in five patients (see figs 2 and 3) and the platelet count was depressed in two patients. Nevertheless, evaluation of myelotoxicity is often inaccurate in patients with acute leukaemia in relapse. Overall, the toxic effects observed were mild and glutaminase treatment was interrupted only in case 9 by metabolic acidosis, which was rapidly reversed by intravenous sodium bicarbonate.

\section{Discussion}

Glutaminase derived from Achromobacter sp can be administered without excessive toxicity and reduces the blood concentrations of glutamine and asparagine to undetectable levels. The 
enzyme is cytotoxic in vivo to leukaemic lymphoblasts and myeloblasts that are resistant to other drugs; it may also depress normal haemopoiesis. The pronounced antileukaemic activity of glutaminase in man demands further evaluation.

The short half life of glutaminase in the blood may be a disadvantage, as frequent injections or intravenous infusion may be necessary. The acinetobacter glutaminase has a half life of only one to two hours in mice but this can be extended to nine to 15 hours by succinylation or glycosylation of the molecule $;^{20}$ these manipulations might similarly affect the achromobacter enzyme. A prolonged blood half life may be unnecessary if tissue depletion of glutamine persists for long periods. Satisfactory tissue depletion occurred in mice given daily intraperitoneal glutaminase, ${ }^{14}$ but in these animals the half life of the enzyme had been prolonged by infection with lactate dehydrogenase virus. Studies in uninfected mice would be more relevant to the treatment of patients. The optimum schedule for administering glutaminase in man may be deduced from the duration of glutamine depletion in the blood after single doses, but clinical trials to compare different schedules will be necessary.

Depletion of glutamine might be expected regularly to produce metabolic acidosis, since the kidney uses glutamine as a source of ammonia to excrete excess hydrogen ions. In mice, however, although glutaminase produces glutamine depletion in many tissues, its concentration in renal tissues rises, apparently because glutamine biosynthesis in the kidney is increased. ${ }^{1+}$ The metabolic acidosis in case 9 might have been attributable to the patient's age; also he received the largest absolute daily dose of glutaminase (40000 IU) because of his size. Close monitoring of blood $\mathrm{pH}$ during glutaminase treatment is desirable until the frequency of metabolic acidosis is established and factors predisposing to it are identified. Lower doses of glutaminase, or prophylactic administration of alkali, might avert this complication.

The place of glutaminase in leukaemia treatment is open to conjecture. Its activity against asparaginase-resistant cells ${ }^{12}$ and in our asparaginase-resistant patients suggests its use in such cases. Glutaminase might prove beneficial in patients who develop allergy to asparaginase and might replace asparaginase altogether since it removes asparagine as well as glutamine: simultaneous deprivation of two amino-acids, rather than of asparagine alone, might confer extra therapeutic advantage.
Finally, glutaminase may have in its own right a place in leukaemia treatment. Its activity in vitro against chronic lymphocytic leukaemia ${ }^{9}$ suggests its study in selected cases, as well as in prolymphocytic leukaemia, ${ }^{21}$ which characteristically is refractory to treatment. Its activity in ALL and AML in the present study suggests that glutaminase should now be studied in patients with acute leukaemia who are at an earlier stage and in better general condition.

We thank Mr J H R Slade (MRE, Porton) for helping to determine blood half lives. The development and production of glutaminase at the Microbiological Research Establishment was supported by a grant from the Department of Health and Social Security.

Requests for reprints should be addressed to Professor A S D Spiers, Division of Medical Oncology, University Hospital, 75 East Newton Street, Boston, Massachusetts, 02118, USA.

\section{References}

1 Borella, L, Journey, L J, and Hiramoto, R, Cancer Research, 1966, 26, 2451.

2 Boyse, E A, et al, Fournal of Experimental Medicine, 1967, 125, 17.

3 Bernard, J, and Boiron, M, Seminars in Haematology, 1970, 7, 427.

4 Tallal, L, et al, Cancer, 1970, 25, 306.

${ }^{5}$ Hill, J M, et al, Cancer Research, 1969, 29, 1574.

6 Capizzi, R L, Bertino, J R, and Handschumacher, R E, Annual Review of Medicine, 1970, 21, 433.

' King, O Y, et al, Cancer, 1974, 33, 611.

8 Roberts, J, Holcenberg, J S, and Dolowy, W C, fournal of Biological Chemistry, 1972, 247, 84.

${ }^{9}$ Holcenberg, J S, Roberts, J, and Dolowy, W C, Nature, 1971, 232, 265.

10 Schrek, R, et al, Acta Haematologica, 1972, 48, 12.

11 Schrek, R, et al, fournal of the National Cancer Institute, 1973, 51, 1103.

12 Schmid, F A, and Roberts, J, Cancer Chemotherapy Reports, 1974, 58, 829.

13 Spiers, A S D, et al, British Medical fournal, 1974, 3, 77.

${ }^{14}$ Holcenberg, J S, Tang, E, and Dolowy, W C, Cancer Research, 1975, 35, 1320.

15 Stanley, J L, Wiblin, C N, and Wade, $\mathrm{H} \mathrm{E}$, in preparation.

${ }^{16}$ MacLennan, A P, Wade, H E, and Hawkins, D C, CNRS Report No 197, $1971,409$.

17 MacLennan, A P, personal communication.

18 Wade, H E, and Phillips, B W, Analytical Biochemistry, 1971, 44, 189.

${ }^{19}$ Benson, J V, Gordon, M J, and Patterson, J A, Analytical Biochemistry, $1967,18,228$.

${ }^{20}$ Holcenberg, J S, Schmer, G, and Teller, D C, fournal of Biological Chemistry, 1975, 250, 4165.

21 Catovksy, D, et al, Lancet, 1973, 2, 232.

\section{Patients, methods, and results}

Three atopic patients (cases 1-3), aged 32, 48, and 54 years, were tested. Each had perennial asthma and had been using oral corticosteroids and a bronchodilator aerosol. In each case the bronchodilator aerosols were symptomatically beneficial and there were no obvious adverse effects. From the first inhalation of the beclomethasone aerosol all three experienced increased breathlessness and wheezing within minutes of using the inhaler. The following tests were made on different days in each of the patients: (1) the patient made two inhalations of the placebo aerosol which contained only the propellant vehicle (trichlorofluoromethane (propellant 11) and dichlorodifluoromethane (propellant 12)); (2) test 1 was repeated but was preceded by inhalation of $20 \mathrm{mg}$ sodium cromoglycate (Intal); (3) test 1 was repeated and followed by the inhalation of two puffs of salbutamol aerosol (Ventolin) 20 minutes later; (4) the patient inhaled the propellant Freons (a) gaseous propellant 11 , obtained by heating liquid propellant 11 to its boiling point, and, on another day, $(b)$ gaseous propellant 12 , obtained as a compressed gas; (5) the patient underwent bronchial provocation tests with histamine; (6) the capacity of gaseous propellant 12 to release histamine from the patients' white blood cells was tested.

The inhalation of the placebo aerosol caused the patients' forced expiratory volume in 1 second $\left(\mathrm{FEV}_{1}\right)$ to fall by $20 \%$ or more from the stable basal value (see table). This fall was maximal after five minutes, and the $\mathrm{FEV}_{1}$ returned to normal over the next 45 to 60 minutes. The inhalation of sodium cromoglycate (test 2) blocked the reaction in two of the three patients, and the inhalation of salbutamol aerosol (test 3 ) resulted in return of the $\mathrm{FEV}_{1}$ to pretest levels (see table). There was no reaction to the inhalation of gaseous propellant 11 or 12 (test 4 ), and bronchial reactivity to histamine was not especially marked (test 5). Only minimal amounts of histamine were released by gaseous propellant 12 from the leucocytes of both the patients and of control subjects, suggesting that Freons were not acting as a histamine releaser.

Four other patients (cases 4-7) with severe perennial asthma, who were 